\title{
Orange juice as dietary source of antioxidants for patients with hepatitis $C$ under antiviral therapy
}

\author{
Danielle Gonçalves ${ }^{a}$, Claudia Lima ${ }^{a}$, Paula Ferreiraa ${ }^{a}$ Paulo Costa ${ }^{b}$, Angela Costac, Walter Figueiredo ${ }^{c}$ \\ and Thais Cesar ${ }^{\mathrm{a}}$
}

${ }^{\text {aFood and Nutrition Department, School of Pharmaceutical Sciences, Universidade Estadual Paulista (UNESP), Araraquara, Brazil; }{ }^{b} C l i n i c a l}$ Analysis Department, School of Pharmaceutical Sciences, Universidade Estadual Paulista (UNESP), Araraquara, Brazil; 'Special Health Service of Araraquara (SESA), Faculty of Public Health, Universidade de Sao Paulo (USP), Araraquara, Brazil

\begin{abstract}
Background: HCV causes alterations in liver metabolism, resulting in biochemical and nutritional disorders. Supplementation with antioxidants has been suggested to minimize the diseases effects.

Objective: This study assessed whether orange juice, a source of citrus flavonoids and vitamin C, may contribute to the treatment of patients with chronic hepatitis $C$.

Design: Anthropometric, hemodynamic, dietary, and biochemical parameters, CRP and liver enzymes were measured in 43 adult patients of both genders who were diagnosed with chronic hepatitis $C$ and were under antiviral therapy. Twenty-three patients were supplemented with orange juice for eight consecutive weeks, while 20 were enrolled as control group.

Results: Following regular use of orange juice, no alterations were found in body mass, fat, and waist circumference. The serum levels of total cholesterol, LDL-cholesterol, CRP and parameters of oxidative stress decreased in the orange juice group. Furthermore, the levels of the liver enzyme AST decreased in those who had high levels before the intervention.

Conclusion: The orange juice was a convenient food in the diet of patients due to the increase in antioxidant capacity and decreased inflammation and cholesterol in blood serum, in addition to maintaining body mass, which protect against the harmful effects caused by the chronic hepatitis $C$ virus.
\end{abstract}

\section{ARTICLE HISTORY}

Received 13 August 2016

Accepted 30 January 2017

\section{KEYWORDS}

Orange juice; chronic hepatitis $C$; biochemical markers; oxidative stress; nutritional status; antioxidants

\section{Introduction}

Hepatitis $\mathrm{C}$ is characterized by liver inflammation resulting from infection by hepatitis $\mathrm{C}$ virus (HCV), which over time can lead to complications such as liver fibrosis, cirrhosis and hepatocellular carcinoma. The presence of $\mathrm{HCV}$ in the cells results in oxidative stress due to the increase of cell metabolism, with the reduction of antioxidant enzymes and the increase of liver enzymes alanine transaminase (ALT) and aspartate transaminase (AST).[1] HCV carriers exhibit high levels of proinflammatory cytokines, such as tumor necrosis factor alpha (TNF- $\alpha$ ), which inhibit insulin signaling in the hepatocytes, and thus increase the risk of insulin resistance and hepatic steatosis.[2]

Patients with chronic hepatitis $\mathrm{C}$ also exhibit high serum levels of $\mathrm{C}$ reactive protein (CRP), which is a marker of inflammation. A correlation has been suggested between increased CRP levels and lipid metabolism disorders in patients with chronic hepatitis C.[3]
Several studies have shown that HCV follows the lipoprotein pathway inside the hepatocytes to survive in the host and increase its viral load. Subsequent to the entry of HCV into cells, the virus replicates in the endoplasmic reticulum, and is secreted into the bloodstream bound to VLDL.[4] Under such conditions HVC exhibits a high degree of infection; conversely, the free virus infection effectiveness is low.[5]

$\mathrm{HCV}$ is a positive-sense single-stranded RNA virus (Flaviviridae family) that contains 9600 nucleotides and, because of its variability, it is classified into six major genotypes designated 1 to 6 according to the sequence in the primary structure, with three major subtypes: $a, b$ and c. The choice and monitoring of antiviral therapy is based on the HCV genotyping test of the patients, which aims to reduce viral replication and delay disease progression.[6] However, this therapy is associated with side effects, including nausea and anemia, which cause nutritional depletion and increase oxidative stress. Some studies have consistently suggested that antioxidant supplements might

CONTACT Thais Cesar tcesar@fcfar.unesp.br E Food and Nutrition Department, School of Pharmaceutical Sciences, Universidade Estadual Paulista (UNESP), Rodovia Araraquara-Jau km 1, Araraquara, SP, 14800-903 Brazil 
minimize the deleterious effects of both the virus and pharmacological treatment.[7]

Freshly squeezed or pasteurized orange juice includes nutrients and bioactive compounds with therapeutic properties, including vitamin $\mathrm{C}$, carotenoids, and citrus flavanones.[8] A portion of $500 \mathrm{ml}$ of orange juice made from sweet oranges (Citrus sinensis) contains around $168 \mathrm{mg}$ of vitamin $\mathrm{C}, 3.65 \mathrm{mg}$ of carotenoids, $16.4 \mathrm{mg}$ of hesperidin and $2.7 \mathrm{mg}$ of naringin, [9] which exhibit antioxidant, hypolipidemic, and antiinflammatory properties.[10] Those flavonoids reduce the 3-hydroxy-3-methyglutaryl coenzyme A reductase (HMG-CoA reductase), acetyl-Coenzyme A acetyltransferase 2 (ACAT2) and microsomal triglyceride transfer protein (MTP), which control the hepatic synthesis of cholesterol and triglycerides.[11] In vitro studies point to the efficacy of naringenin against $\mathrm{HCV}$ production by reducing or inhibiting these enzymes activity.[12]

Although previous studies suggest that antioxidants might improve oxidative imbalance caused by $\mathrm{HCV}$ infection, $[13,14]$ there are no studies on the effect of citrus juice on infected patients. In addition, HCV infected patients were chosen instead of $\mathrm{HBV}$ and $\mathrm{HAV}$, because of its higher prevalence ( $>60 \%$ worldwide), and although the other types of hepatitis are more lethal, they are acute episodes and can be prevented by vaccination. Thus, the objective of this study was to show that orange juice can play a supporting role in the treatment of chronic hepatitis C. For that purpose, the consumption of orange juice was tested in patients with chronic hepatitis $\mathrm{C}$ and treated with antiviral therapy, and the nutritional status and biochemical and oxidative stress parameters were assessed and compared to the control group.

\section{Material and methods}

\section{Subjects}

This was a randomized clinical trial, controlled, parallel-arm study, conducted in individuals with chronic hepatitis C. Uninfected subjects were not included in this proposal because the effect of an antioxidant supplement would not be perceived in such condition. Screening of volunteers was performed at Special Health Service of Araraquara (SESA), which is a region reference center for infectious diseases. Co-authors MD Figueiredo and NP Costa assisted the screening of patients with chronic hepatitis C, and MS Gonçalves and MS Lima performed the interviews. During the interview, HCV patients were investigated with regard to comorbidities, use of drugs, consumption of alcohol and smoking. All volunteers were invited to participate in the study: patients registered at SESA, aged $\geqslant 18$ years, positive HCV-RNA serum and under hepatitis $\mathrm{C}$ treatment. Volunteers were evaluated for viral co-infection before the beginning of this study, using immunological tests recommended by the Brazilian Ministry of Health: HBsAg, total anti-HBc for hepatitis B; anti-HAV total and IgG for hepatitis A; anti-HIV 1/ 2 for HIV. The inclusion criteria of the subjects were the detection of circulating HCV RNA by polymerase chain reaction using the COBAS AMPLICORTM HCV 2.0 assay (Roche, Branchburg, NJ, USA) and negative HBV surface antigen or antibodies to HIV. Viral genotyping was performed using the HCV Genotype 2.0 Assay-LiPA (Versant ${ }^{\circledR} \mathrm{HCV}$-Siemens, Tarrytown, NY, USA). The exclusion criteria were co-infection with other viruses as hepatitis B virus (HBV) and human immunodeficiency virus (HIV), and presence of diabetes mellitus or ascites, and elevation in serum ferritin levels.

Seventy patients with chronic hepatitis C, who had undergone liver biopsy before treatment with drugs, were enrolled. The histological classification of liver biopsy was according to the METAVIR scale (Brazilian Ministry of Health), where F0 represents a normal liver architecture without fibrosis; F1 shows portal fibrosis without septa; F2 indicates portal fibrosis with rare septa; F3 shows numerous septa without fibrosis and, F4 indicates cirrhosis. All patients were being treated with pegylated interferon combined with ribavirin, according to the Clinical Protocol and Therapeutic Guidelines for Viral Hepatitis C and Co-infections of the Brazilian Health Ministry.[15] This study followed the guidelines of the Declaration of Helsinki and all patients signed an informed written consent. The Ethical Board on Research of the School of Pharmaceutical Sciences of UNESP approved all procedures involving human patients (Protocol \#46/2011). This clinical study has been declared to the website ClinicalTrials.com under the number NCT03026569.

\section{Experimental protocol}

The subjects were divided into two groups: (1) control, with no regular consumption of orange juice; and (2) orange juice group, supplemented with orange juice $\left(500 \mathrm{ml} \mathrm{day}{ }^{-1}\right)$ for eight weeks. Each participant of the second group was given 41 week $^{-1}$ of $100 \%$ commercial pasteurized orange juice (Pera Rio variety) produced by Citrosuco, Matao, SP, Brazil ${ }^{\bullet}$. They were instructed to drink orange juice in two daily portions over the eight consecutive weeks of the experiment. Patients from both groups were asked to maintain their usual lifestyle, diet, and physical activity, and 
they were checked weekly by the researcher's team. Assessment of anthropometric data, dietary intake, as well as blood sample collection for biochemical analysis, was performed in all participants on the first and last day of the experiment.

\section{Assessment of anthropometric data}

Body mass was measured by trained personnel using a digital scale, and the height was measured using a standing stadiometer. Waist circumference was measured midway between the costal margin and iliac crest. Biceps, triceps, subscapular, and suprailiac skinfolds were measured using a Lange Skinfold Caliper ${ }^{\circledR}$, and the patients' total body fat was calculated.[16] All measures were made three times and the average was calculated.

\section{Assessment of food and nutrient intake}

Dietary intake assessments included three 24-h dietary recalls, collected in two weekdays and one weekend day, and one food-frequency questionnaire. The study dietitians made two complete dietary evaluations, in the beginning and in the end of the experimental period. The participants were previously instructed about food portions to facilitate estimation of intake. Daily energy and nutrient intakes were estimated using the software 'NutWin' version 3.1, Sao Paulo School of Medicine - Federal University of São Paulo (UNIFESP).

\section{Biochemical assessment}

A blood sample $(32 \mathrm{ml})$ was collected for biochemical assessment following a $12 \mathrm{~h}$ fast at the beginning and the end of the experimental period. The blood serum was separated by centrifugation at $3000 \times g$ for $10 \mathrm{~min}$ and stored at $-80^{\circ} \mathrm{C}$ until the analyses performance. The tests were performed at the Diagnostic Reference Center Laboratory, FCFAR-UNESP. The serum concentrations of total cholesterol, HDL-cholesterol, LDL-cholesterol, triglycerides, glucose, CRP, AST, ALT, gamma-glutamyl transpeptidase $(\gamma-\mathrm{GT})$, and alkaline phosphatase (ALP) were assessed using Labtest $^{\oplus}$ kits (Lagoa Santa, MG, Brazil) in a photometric system using the Labmax $240^{\circ}$ device (Labtest ${ }^{\oplus}$, Lagoa Santa, MG, Brazil). Insulin was assessed by electrochemiluminescence, and LDL-cholesterol was calculated according to Friedewald et al. (1972) [17]. Insulin resistance was calculated using the homeostasis model assessment index (HOMA-IR), [18] and $>2.71$ was used as the cutoff point for the Brazilian population.

\section{Oxidative stress assessment}

The 2,2'-azinobis(3-ethylbenzthiazoline sulfonate) (ABTS) [19] assay was used to determine the total antioxidant capacity of subjects' serum. In this method, an $\mathrm{ABTS}^{-+}$radical is generated in the assay and the antioxidant activity of the sample against the radical is measured according to the reduction of the $\mathrm{ABTS}^{\circ+}$ by the hydrogen-donating antioxidant present on the sample. Trolox was used as standard. Five $\mu$ of a $7 \mathrm{mM}$ solution of ABTS was added along with $88 \mathrm{ml}$ of a $140 \mathrm{mM}$ potassium persulfate solution and the mixture left at room temperature, in the dark for $16 \mathrm{~h}$. Before use, the solution was diluted (1:88) with a $10 \mathrm{mM}$ sodium phosphate buffer, $\mathrm{pH} 7.4$ (initial absorbance at $734 \mathrm{~nm}$ of 0.7 ). Five $\mu$ of Trolox standard $(0,0.50,0.75,1.00,1.25,1.50,1.75,2.00 \mathrm{mM})$ and $5 \mu \mathrm{l}$ of each serum samples were mixed with $300 \mu \mathrm{l}$ of ABTS $^{+}$solution. After $6 \mathrm{~min}$, absorbance at $734 \mathrm{~nm}$ was measured in a microplate reader (Epoch, Biotek, Winooski, VT, USA). Total antioxidant capacity was based on the molar extinction coefficient of Trolox obtained by an analytical curve.

The thiobarbituric acid-reactive substances (TBARS) assay was used as an indicator of lipid peroxidation in subject serum.[20, Although not specific for lipid peroxides, because thiobarbituric acid (TBA) also reacts with protein, sucrose and metabolites in the plasma, it is a usual method for this purpose. For the assay performance the 1,1,3,3-tetraethoxypropane (TEP) was used as standard for malondialdehyde (MDA) equivalents $(1 \mathrm{~mol}$ TEP $=1 \mathrm{~mol} \mathrm{MDA}$ in reacting with thiobarbituric acid - TBA). Two hundred $\mu$ l of MDA standard $(0,1.25,1.88,2.50,3.13,3.75,6.25$, and $12.50 \mu \mathrm{M})$ and $200 \mu \mathrm{l}$ of each serum sample were mixed with $200 \mu \mathrm{l}$ of sodium dodecyl sulfate (SDS) and then $500 \mu \mathrm{l}$ of staining reagent $\left(5.3 \mathrm{mg} \mathrm{ml}^{-1}\right.$ of TBA diluted in $20 \%$ acetic acid, $\mathrm{pH} 3.5$ ) were vortexed, incubated at $100^{\circ} \mathrm{C}$ for $60 \mathrm{~min}$, and cooled on ice for $10 \mathrm{~min}$. The standards and samples were centrifuged at $8000 \times \mathrm{g}$ for $10 \mathrm{~min}$, and the absorbance of the supernatant was determined at $532 \mathrm{~nm}$ in a microplate reader (Epoch, Biotek, Winooski, VT, USA). TBARS concentration was based on the molar extinction coefficient of MDA obtained by an analytical curve.

\section{Statistical analysis}

All parameters before and after treatment were compared between the juice group and the control group using the general linear model of repeated measures analysis. Differences in baseline patients' characteristics between the two groups were analyzed by one-way analysis of variance (ANOVA). The LSD signed rank post-test was 
used to assess significant changes in parameters after the start of treatment in each group. All data are expressed as means \pm S.D. Differences were considered statistically significant at $p<0.05$. The analyses were performed by software IBM SPSS Statistics (v.21, SPSS: an IBM Company, Chicago, IL, USA).

\section{Results}

\section{Study population}

From 70 screened patients, 22 subjects did not meet eligibility criteria, and 48 were random divided into the orange juice $(n=24)$ and control group $(n=24)$. None of them was on lipid-lowering drugs that could be a confounder effect, since the drug blocks replication and release of HCV. During the course of the experiment, one patient was excluded orange juice group due to high levels of ferritin, and four were excluded from control group due to diarrhea (one) and to no adherence to hepatitis drugs (three). At the end, 43 participants consistently adhered to the experimental protocol, as control group $(n=20)$ and orange juice group $(n=23)$. Patients from the orange juice group reported high compliance to the juice supplementation.

Clinical records of the patients showed a predominance of chronic infection by HCV genotype 1 (69.4\%), followed by genotypes 3 (25.8\%) and 2 (4.8\%). Furthermore, liver biopsy showed that the majority of patients $(68 \%)$ had moderate inflammatory activity, ranging from F0 grade without fibrosis (8\%); F1 grade with portal fibrosis (36\%); F2 grade with scars in the liver areas that contains blood vessels (16\%); F3 grade with bridges of fibrosis connected to other areas with fibrosis (28\%); and finally, F4 grade with advanced scars or more severe fibrosis with cirrhosis (12\%).[15]

\section{Assessment of anthropometric data}

Anthropometric data before and after the period of intervention with orange juice are presented in Table 1. No differences were detected in body weight, BMI, body fat and waist measures of the participants in the beginning or in the end of the study, for both groups (orange juice and control).

\section{Assessment of food and nutrient intake}

Total energy, carbohydrate, lipid, protein, vitamins and minerals were obtained from three-day dietary records at the beginning and end of the experiment, and the results are presented in Table 1. The two groups did not differ significantly for total energy consumption, macronutrients and micronutrients, except for protein and ion intake, which were higher in the control group before the study. After intervention with orange juice, increases of protein (21\%) and iron (15\%) were detected in this group, which became similar to the control group. As expected, intakes of vitamin C (209\%) and folate $(33 \%)$ were higher in the juice group. No changes were observed in the dietary intake for control group. A summary of the food items consumed by both groups, separated in food groups, is

Table 1. Anthropometrical and dietary intake from chronic hepatitis $C$ patients before and after supplementation of orange juice.

\begin{tabular}{|c|c|c|c|c|}
\hline \multirow[b]{2}{*}{ Parameters } & \multicolumn{2}{|c|}{ Orange juice $(n=23)$} & \multicolumn{2}{|c|}{ Control $(n=20)$} \\
\hline & Baseline & After & Baseline & After \\
\hline \multicolumn{5}{|l|}{ Anthropometrical } \\
\hline Body mass (kg) & $72.6 \pm 12.8$ & $71.6 \pm 12.1$ & $71.9 \pm 11.5$ & $72.0 \pm 11.8$ \\
\hline BMI $\left(\mathrm{kg} \mathrm{m}^{-2}\right)$ & $23.2 \pm 3.8$ & $22.8 \pm 3.5$ & $24.6 \pm 3.6$ & $24.6 \pm 3.6$ \\
\hline Waist circumference $(\mathrm{cm})$ & $91 \pm 13$ & $90 \pm 13$ & $89 \pm 10$ & $90 \pm 10$ \\
\hline Body fat $(\%)$ & $35 \pm 12$ & $33 \pm 10$ & $28 \pm 7$ & $29 \pm 7$ \\
\hline \multicolumn{5}{|l|}{ Dietary intakes } \\
\hline Energy (kcal) & $2080 \pm 623$ & $2146 \pm 531$ & $2348 \pm 978$ & $2403 \pm 953$ \\
\hline Carbohydrates (g) & $252 \pm 68$ & $283 \pm 66$ & $312 \pm 137$ & $320 \pm 133$ \\
\hline Lipids (g) & $86 \pm 35$ & $77 \pm 24$ & $85 \pm 46$ & $85 \pm 46$ \\
\hline Protein (g) & $72 \pm 23^{\mathrm{a}}$ & $87 \pm 25^{b}$ & $104 \pm 40^{b}$ & $104 \pm 41^{b}$ \\
\hline Calcium (mg) & $583 \pm 264$ & $544 \pm 241$ & $768 \pm 381$ & $760 \pm 359$ \\
\hline Iron (mg) & $11.6 \pm 3.9^{\mathrm{a}}$ & $13.3 \pm 4.2^{b}$ & $14.7 \pm 5.5^{b}$ & $14.8 \pm 5.6^{b}$ \\
\hline Vitamin C (mg) & $80 \pm 53^{a}$ & $247 \pm 72^{b}$ & $126 \pm 181^{\mathrm{a}}$ & $124 \pm 181^{a}$ \\
\hline Folate $(\mu \mathrm{g})$ & $131 \pm 58^{\mathrm{a}}$ & $174 \pm 38^{b}$ & $97 \pm 77^{\mathrm{a}}$ & $96 \pm 79^{a}$ \\
\hline Vitamin E (mg) & $37 \pm 20$ & $34 \pm 10$ & $22 \pm 16$ & $23 \pm 16$ \\
\hline Sodium (g) & $2.3 \pm 0.6$ & $2.1 \pm 0.7$ & $3.1 \pm 1.3$ & $3.0 \pm 1.3$ \\
\hline
\end{tabular}

BMI, body mass index.

Mean values \pm SD before and after ingestion of $500 \mathrm{ml} \mathrm{day}^{-1}$ orange juice for eight weeks.

General linear model of repeated measures analysis followed by one-way and post-hoc LSD test, $p \leq 0.05$.

Values with the same letter in a row are not significantly different, while the different letters are statistically significant. 
Table 2. Main food items often consumed by all patients separated in food groups.

\begin{tabular}{lll}
\hline Food group & \multicolumn{1}{c}{ Daily consumption } & \multicolumn{1}{c}{ Weekly consumption } \\
\hline Cereal & Bread, rice, sweet cookies, cream cracker & Potato, pasta, cake, cassava \\
Vegetable & Tomato, lettuce, spinach, zucchini, cabbage, chayote & Carrot, eggplant, broccolis, arugula \\
Fruits & Banana, apple, papaya & Pear, peach, mango, orange \\
Protein & Beans, meat, poultry, pork & Green beans, eggs, nuts, ham, sausage \\
Milk & Milk, yogurt & Cream cheese, mozzarella \\
Fats, oils and sweets & Margarine, butter, chocolate, candies & Sweet desserts (jelly fruit) \\
Drinks & Coffee, sugary beverages, fruit juice & Sodas, tea \\
\hline
\end{tabular}

showed on Table 2. No difference was found between the orange juice group and the control group, demonstrating very similar choices of foods and food groups for all subjects.

\section{Biochemical assessment}

In the post-intervention assessment, the serum concentrations of total cholesterol and LDL-cholesterol decreased only in the juice group by $9.5 \%$ and $12.5 \%$, respectively.(Table 3) No changes were found in the HDL-cholesterol and triglycerides concentrations after the dietary supplementation. Concentration of glucose and insulin did not change after the study period, and also, regular intake of orange juice did not induce significant changes on marker of insulin resistance (HOMA-IR) in the investigated sample. But participants of the control group presented HOMA-IR threshold higher than 2.71, which can be a risk for development of insulin resistance. Assessment of the inflammatory profile showed that the serum levels of CRP decreased by $77 \%$ in the juice group (Table 3 ). The regular intake of orange juice decreased TBARS $(44.5 \%)$ in the juice group patients and improved the total antioxidant capacity (2.5\%) in these patients while the antioxidant capacity in the control group patients decreased (1.2\%) during the experimental period, without changes in the lipid peroxidation (Table 3 ).

The levels of the liver enzymes AST, ALT, ALP and $\gamma$-GT did not exhibit changes following the intervention (Table 3). A re-assessment of the liver metabolic enzymes in patients who exhibited levels above the normal threshold before the intervention found reductions in the serum levels of AST of the juice group (Table 4). No change was observed in control group.

\section{Discussion}

The original design of this study was to verify if the habitual consumption of orange juice could lower the oxidative stress and inflammation of $\mathrm{HCV}$ patients. In order to prove this hypothesis, we have tested two groups of patients with $\mathrm{HCV}$ infection: one group drinking $500 \mathrm{ml}$ of orange juice daily, and the other without drinking orange juice regularly. After regular consumption of orange juice, hepatitis C patients under antiviral therapy have had an improvement of the antioxidant capacity, lipid profile, liver inflammatory

Table 3. Biochemical and oxidative stress measurements of chronic hepatitis $C$ patients before and after supplementation of orange juice.

\begin{tabular}{|c|c|c|c|c|}
\hline \multirow[b]{2}{*}{ Parameters } & \multicolumn{2}{|c|}{ Orange juice $(n=23)$} & \multicolumn{2}{|c|}{ Control $(n=20)$} \\
\hline & Baseline & After & Baseline & After \\
\hline Total cholesterol $\left(\mathrm{mg} \mathrm{dl}^{-1}\right)$ & $142 \pm 24^{b}$ & $122 \pm 24^{\mathrm{a}}$ & $136 \pm 29^{a}$ & $134 \pm 29^{a}$ \\
\hline LDL-C $\left(\mathrm{mg} \mathrm{dl}^{-1}\right)$ & $74 \pm 23^{a}$ & $61 \pm 24^{b}$ & $79 \pm 24^{\mathrm{a}}$ & $79 \pm 23^{a}$ \\
\hline $\mathrm{HDL}-\mathrm{C}\left(\mathrm{mg} \mathrm{dl}^{-1}\right)$ & $41 \pm 11$ & $36 \pm 10$ & $32 \pm 7$ & $32 \pm 7$ \\
\hline Triglycerides $\left(\mathrm{mg} \mathrm{dl}^{-1}\right)$ & $121 \pm 51$ & $111 \pm 30$ & $129 \pm 56$ & $118 \pm 55$ \\
\hline Glucose $\left(\mathrm{mg} \mathrm{dl}^{-1}\right)$ & $94 \pm 17$ & $93 \pm 12$ & $96 \pm 13$ & $95 \pm 14$ \\
\hline Insulin $\left(\mathrm{mg} \mathrm{dl}^{-1}\right)$ & $8.4 \pm 5.0$ & $8.1 \pm 5.5$ & $12.7 \pm 6.0$ & $12.4 \pm 6.2$ \\
\hline HOMA-IR & $2.1 \pm 1.5$ & $2.1 \pm 1.7$ & $3.1 \pm 1.9$ & $2.9 \pm 1.8$ \\
\hline $\operatorname{ALT}\left(\mathrm{U} \mathrm{I}^{-1}\right)$ & $66 \pm 37$ & $57 \pm 31$ & $69 \pm 51$ & $70 \pm 51$ \\
\hline AST $\left(U^{-1}\right)$ & $68 \pm 33$ & $58 \pm 31$ & $74 \pm 43$ & $72 \pm 46$ \\
\hline $\operatorname{ALP}\left(\mathrm{U} \mathrm{I}^{-1}\right)$ & $78 \pm 27$ & $70 \pm 26$ & $66 \pm 18$ & $64 \pm 16$ \\
\hline$\gamma-G T\left(U^{-1}\right)$ & $71 \pm 57$ & $65 \pm 52$ & $77 \pm 65$ & $76 \pm 66$ \\
\hline $\operatorname{CRP}\left(\mathrm{mg} \mathrm{l}^{-1}\right)$ & $2.59 \pm 1.64^{b}$ & $0.44 \pm 0.61^{\mathrm{a}}$ & $0.68 \pm 0.61^{\mathrm{a}}$ & $0.44 \pm 0.35^{\mathrm{a}}$ \\
\hline ABTS (mM) & $1.60 \pm 0.04^{\mathrm{a}}$ & $1.64 \pm 0.03^{b}$ & $1.70 \pm 0.02^{\mathrm{d}}$ & $1.68 \pm 0.02^{c}$ \\
\hline TBARS $(\mu \mathrm{M})$ & $2.72 \pm 1.43^{b}$ & $1.51 \pm 0.68^{\mathrm{a}}$ & $3.14 \pm 1.01^{b c}$ & $3.65 \pm 1.67^{c}$ \\
\hline
\end{tabular}

ALT, alanine transaminase; AST, aspartate transaminase; ALP, alkaline phosphatase; CRP, C-reactive protein; $\gamma$-GT, gamma-glutamyl transpeptidase.

Mean values \pm SD before and after ingestion of $500 \mathrm{ml}^{-1}$ orange juice for eight weeks.

General linear model of repeated measures analysis followed by one-way and post-hoc LSD test, $p \leq 0.05$.

Values with the same letter in a row are not significantly different, while the different letters are statistically significant. 
Table 4. Effect of orange juice on liver enzymes of the chronic hepatitis $C$ patients according to their hepatic levels before supplementation.

\begin{tabular}{|c|c|c|c|c|c|c|}
\hline \multirow{2}{*}{$\begin{array}{l}\text { Enzyme level } \\
\text { Normal }\end{array}$} & \multicolumn{3}{|c|}{ Orange juice } & \multicolumn{3}{|c|}{ Control } \\
\hline & $n$ & Baseline & After & $n$ & Baseline & After \\
\hline ALT: 11-45 (U I') & 6 & $27 \pm 12$ & $26 \pm 13$ & 8 & $22 \pm 13$ & $25 \pm 14$ \\
\hline & 6 & & & & & \\
\hline & 18 & & & 19 & & \\
\hline $\begin{array}{l}\text { Y-GT: 7-58 }\left(\mathrm{U} \mathrm{I}^{-1}\right) \\
\text { High }\end{array}$ & 12 & & & 7 & $28 \pm 7$ & $27 \pm 9$ \\
\hline & 17 & & $66 \pm$ & 12 & $107 \pm$ & $106 \pm$ \\
\hline$\left(\mathrm{U} \mathrm{I}^{-1}\right)$ & 17 & $81 \pm 26^{b}$ & $65 \pm 22^{a}$ & 16 & $86 \pm 42^{b}$ & $84 \pm 44^{b}$ \\
\hline & 5 & $159 \pm 48$ & $142 \pm 48$ & 1 & nd & nd \\
\hline Y-GT: $>58\left(\mathrm{U} \mathrm{I}^{-}\right.$ & 11 & $144 \pm 6 /$ & $110 \pm 58$ & 13 & $108 \pm 67$ & $107 \pm 67$ \\
\hline
\end{tabular}

ALT, alanine transaminase; AST, aspartate transaminase; ALP, alkaline phosphatase; CRP, C-reactive protein; MDA, malondialdehyde; $\gamma$-GT, gammaglutamyl transpeptidase.

nd: not detected.

Mean values \pm SD before and after ingestion of $500 \mathrm{ml} \mathrm{day}^{-1}$ orange juice for eight weeks.

General linear model of repeated measures analysis followed by one-way and post-hoc LSD test, $p \leq 0.05$.

Values with the same letter in a row are not significantly different, while the different letters are statistically significant.

markers, and aspartate transaminase level. All of these results indicate that orange juice is a suitable food for chronic $\mathrm{C}$ hepatitis patients, with the advantage of lack of toxicity and high supply of dietary antioxidant compounds.

Patients undergoing pharmacological treatment frequently exhibit anorexia, weight loss, and lower quality of life because of the medication employed.[22] Regular intake of orange juice promoted an enhancement in the diet of the orange juice group patients by increasing vitamin $\mathrm{C}$ and folate intake. Although some authors have suggested that orange juice intake might result in weight gain due to the sugar content,[23] in our study, eight-week treatment with orange juice did not affect weight or body fat and thus represented a positive contribution to the maintenance of the patients' nutritional status. According to previous studies, higher body fat and BMI were significantly associated with hepatic steatosis and it may contribute to growth of steatosis in patients with chronic hepatitis C.[24] Certainly, orange juice did not contribute to those deleterious effects, because it was not associated with elevation of BMI or abdominal fat, and did not caused changes in waist circumference, indicating a potential low risk for metabolic syndrome development.[25]

The harmful effects of chronic hepatitis $\mathrm{C}$ on patients' nutritional status might be improved by a dietary pattern aimed to the special needs of this clinical condition. Before the intervention, protein intake of the juice group was below the levels recommended, whereas the carbohydrate intake was within the recommended range, and lipid intake was high.[26] Following the intervention with orange juice, the energy intake rose to $98.5 \%$ of the recommended values, and the macronutrient intake became appropriate. In the control group, the dietary energy, carbohydrate and protein were above the recommended levels, and lipids were at the maximum limit of the nutritional guidelines before the intervention. At the end the experimental period, there were no changes in food intake of patients in this group. Intakes of iron, vitamin $\mathrm{C}$, and vitamin $\mathrm{E}$ were within the recommended range before and after the intervention in both groups, but calcium and folate remained low across the full period of the study. For both groups the sodium levels were rather high during the experiment period. To date, there are no recommendations available for the use of dietary supplements in this clinical condition. Nevertheless, some studies have already reported an improvement in patients infected by HCV with supplements of zinc,[13] vitamin E and C [27] among other nutrients.[28]

Consumption of $500 \mathrm{ml} \mathrm{day}{ }^{-1}$ of orange juice increased dietary intake of vitamin $\mathrm{C}$, naringin, and hesperidin.[8] These compounds might have contributed to the reduction of cholesterol and LDL-cholesterol levels in our patients who consumed orange juice. Before the intervention, the blood serum lipids of both groups were within the recommended range, agreeing with others who found appropriate levels of total cholesterol in patients with chronic hepatitis C compared with non-infected individuals.[29,30] Low levels of blood cholesterol are a common finding in patients with $\mathrm{HCV}$, because intracellular cholesterol is used to viral replication.[30] Inside the hepatocytes, HCV replication requires both triacylglycerol and cholesterol for the production of virions. These demands are provide by an increase on genes activity related to lipid biosynthesis, while the low-density lipoprotein receptor activity is reduced.[31] In addition, HCV infection induces synthesis of fatty acids, which increases lipogenesis and contribute to the steatosis and the tumorigenesis.[32]

Statins have been associated with improvement of virological response, decreasing of liver fibrosis and incidence of hepatocellular carcinoma in patients with chronic hepatitis C. But, statin can also elevate liver enzymes and subsequently the hepatotoxicity, and because of this it is recommended only for patients with high cardiovascular risk and stable aminotransferases levels.[33,34] Therefore, statins are used less frequently in patients with chronic hepatitis C compared to those not infected.[35]

The bioactive compounds in orange juice, i.e. citrus flavonoids naringin and hesperidin, might reduce the availability of cholesterol to hepatic cell by inhibiting 
the ACAT2 enzyme and reduce the availability of triglycerides to VLDL assembly by decreasing the activity of MTP, thus decreasing the synthesis and secretion of these liver lipids. Inhibition of this important metabolic step in the production of VLDL stimulates LDL receptor expression, with a consequent reduction in serum LDLcholesterol.[11] Studies have shown that after consumption of orange juice or isolated flavanones there was detected an increased concentration of metabolites of hesperidin and naringin, which was associated with hypolipidemic effects.[36-39] Therefore, citrus flavonoids can positively modulate lipid metabolism, decreasing the production and secretion of the HCV.[12]

Decreasing blood serum lipids after orange juice intake by healthy individuals has been associated not only with the action of flavanones but also with levels of vitamin C.[40] Actually, it was showed that vitamin C-rich foods, such as orange juice, boosted levels of vitamin $C$ in the plasma similarly to the supplementation with higher levels of vitamin $\mathrm{C}$, reaching a maximum concentration of $200 \mathrm{mg}$. Therefore, the consumption of $500 \mathrm{ml} \mathrm{day}{ }^{-1}$ of orange juice that contains $250 \mathrm{mg}$ of vitamin $\mathrm{C}$ seems to be in agreement with this observation.[41]

Oxidative stress is another prominent clinical feature associated with hepatitis $\mathrm{C}$ infection. [42] HCV produces more ROS than other hepatitis viruses and significantly influences the development of hepatic inflammation. On the other hand, the HCV adaptation to oxidative stress is key to its survival in the host.[43,44] Antiviral therapy also stimulates oxidative stress. Patients under anti-HCV therapy present elevated lipid peroxidation and reduced levels of the vitamins C, B and $\alpha$-tocopherol, in addition to antioxidant hepatic enzyme activity.[7,45] However, studies suggest that antioxidants may interfere in HCV replication, to improve liver enzyme levels, to protect against liver cell damage and to render interferon antiviral therapy more effective.[44]

As observed in our study, the regular intake of orange juice enhanced the total antioxidant capacity and decreased TBARS concentration in the blood serum. These effects can be associated to the antioxidants compounds of orange juice. It was shown that hesperidin decreases pro-oxidant enzymes [46] and increases antioxidant hepatic enzymes.[47] This increase on antioxidant capacity can be strongly associated to vitamin $\mathrm{C}$ from orange juice. This vitamin is a natural water-soluble free radical scavenger with the ability to donate two electrons from the double bond of the 6-carbon. In this process, oxidized vitamin $\mathrm{C}$ generates a stable intermediate product, dehydroascorbic acid (DHA), which can be taken up by erythrocytes and reduced to vitamin $\mathrm{C}$ again via endogenous glutathione reductase.[48-50] A relevant role of vitamin $C$ on plasma is to preserve $\alpha$-tocopherol by recycling it by oxidation. Similar to vitamin $\mathrm{C}, \alpha-$ tocopherol donates two electrons and become a less toxic product, $\alpha$-tocopheroxyl. To be an effective antioxidant vitamin, this oxidized $a$-tocopherol must be reduced, but this process is slower than ascorbate recycling. Therefore, it is likely that $\alpha$-tocopherol is recycled in the cell membrane by a mechanism that involves enzymatic ascorbate recycling via $\alpha$-tocopheroxyl.[51]

Some studies also suggest using dietary antioxidants to reduce liver enzyme levels in $\mathrm{HCV}$-infected individuals.[13,52] In the present study, the use of orange juice was associated with a reduction in serum levels of AST in patients who exhibited increased levels before the dietary intervention. Studies reported that the administration of hesperidin induced a significant reduction in serum AST, ALT, and ALP levels, in addition to reducing oxidative stress in rats with lipopolysaccharide (LPS)-induced hepatotoxicity, thus suggesting that this flavanone might protect against liver damage.[53] Similar results were observed after supplementation with naringenin alone [54] or associate with vitamins $\mathrm{C}$ and $\mathrm{E}$ in rats submitted to cadmiuminduced hepatotoxicity.[55]

As hepatitis $C$ virus infection causes liver inflammation, [2] CRP is a plasmatic protein released by the liver through stimulation by IL- 6 and IL- $1 \beta$ in response to an acute inflammatory process; however, elevated CRP plasma levels (between 3 and $10 \mathrm{mg} \mathrm{l}^{-1}$ ) have been found in conditions of low and continuous chronic inflammation. [56] CRP levels are higher among individuals infected with HCV compared with uninfected individuals; however, CRP levels in individuals treated with antiviral therapy are lower in comparison to untreated subjects.[3] In our study, the patients of the control group already exhibited CRP normal levels $\left(<1.0 \mathrm{mg} \mathrm{l}^{-1}\right)$, and this level was not changed at the end of the study; however, the patients who were supplemented with orange juice showed elevated CRP levels at baseline, but this concentration was reduced significantly after the intervention with orange juice. Similar results were also obtained in a study conducted with healthy individuals,[57] in which orange juice intake was associated with reduced CRP and serum cholesterol levels. Consequently, those authors suggested including orange juice as a daily part of a healthy diet.

\section{Conclusion}

To conclude, we suggest that orange juice intake should be encouraged in patients with chronic hepatitis $\mathrm{C}$ undergoing antiviral therapy. This suggestion is based on the positive effects of this ordinary food on lower levels of serum lipids, AST, CRP, oxidative stress 
and nutritional status preservation. It is suggested that these effects resulted from interactions between vitamin $\mathrm{C}$ and citrus flavonoids, concentrations of which can be influenced by processing techniques.

\section{Acknowledgments}

The authors thank CAPES for grant scholarship to Danielle Gonçalves, Claudia Lima and Paula Ferreira, and also Diagnostic Reference Center Laboratory, FCFAR-UNESP, for clinical analysis.

\section{Disclosure statement}

No potential conflict of interest was reported by the authors.

\section{Funding}

The authors thank financial support of Programa de Apoio ao Desenvolvimento Cientifico da Faculdade de Ciencias Farmaceuticas at UNESP (PADC/FCFAr), Citrosuco S/A and CitrusBR for supplying orange juice for this study.

\section{References}

[1] Rosen HR. Chronic hepatitis C infection. N Engl J Med. 2011;77:2429-2438.

[2] El-Zayadi A-R, Anis M. Hepatitis C virus induced insulin resistance impairs response to antiviral therapy. World J Gastroenterol. 2012;18:212-224. DOI:10.3748/ wjg.v18.i3.212

[3] Huang CF, Hsieh MY, Yang JF, et al. Serum hs-CRP was correlated with treatment response to pegylated interferon and ribavirin combination therapy in chronic hepatitis C patients. Hepatol Int. 2010;4:621-627. DOI:10.1007/s12072-010-9200-8

[4] Bartenschlager R, Cosset F-L, Lohmann V. Hepatitis C virus replication cycle. J Hepatol. 2010;53:583-585.

[5] Petit JM, Minello A, Duvillard L, et al. Cell surface expression of LDL receptor in chronic hepatitis C: correlation with viral load. Am J Physiol Endocrinol Metab. 2007;293:E416-E420. DOI:10.1152/ajpendo.00091.2007

[6] Messina JP, Humphreys I, Flaxman A, et al. Global distribution and prevalence of hepatitis $\mathrm{C}$ virus genotypes. Hepatology. 2015;61:77-87. DOI:10.1002/hep.27259

[7] Lin CC, Yin MC. Vitamins B depletion, lower iron status and decreased antioxidative defense in patients with chronic hepatitis $\mathrm{C}$ treated by pegylated interferon alfa and ribavirin. Clin Nutr. 2009;28:34-38. DOI:10.1016/j. clnu.2008.09.003

[8] Franke AA, Cooney RV, Henning SM, et al. Bioavailability and antioxidant effects of orange juice components in humans. J Agric Food Chem. 2005;53:5170-5178. DOI:10.1021/jf050054y

[9] Bhagwat S, Haytowitz DB, Holden JM U.S. department of agriculture database for the flavonoid content of selected foods. USDA. 2013 Dec [cited 2014 Mar 04]. Release 3.1: [about p. 37]. Available from: https://www. ars.usda.gov/SP2UserFiles/Place/80400525/Data/Flav/ Flav3-1.pdf

[10] Sánchez-Moreno C, Cano MP, Ancos B, et al. Effect of orange juice intake on vitamin $\mathrm{C}$ concentrations and biomarkers of antioxidant status in humans. Am J Clin Nutr. 2003;78:454-460.

[11] Wilcox LJ, Borradaile NM, Dreu LE, et al. Secretion of hepatocyte apoB is inhibited by the flavonoids, naringenin and hesperetin, via reduced activity and expression of ACAT2 and MTP. Lipid Res. 2001;42:725-734.

[12] Nahmias Y, Goldwasser J, Casali M, et al. Apolipoprotein $\mathrm{B}$-dependent hepatitis $\mathrm{C}$ virus secretion is inhibited by the grapefruit flavonoid naringenin. Hepatology. 2008;47:1437-1445. DOI:10.1002/hep.22197

[13] Murakami Y, Koyabu T, Kawashima A, et al. Zinc supplementation prevents the increase of transaminase in chronic hepatitis $\mathrm{C}$ patients during therapy with pegylated interferon $a-2 b$ and ribavirin. J Nutr Sci Vitaminol. 2007;53:213-218.

[14] Farias MS, Budni P, Ribeiro CM, et al. Antioxidant supplementation attenuates oxidative stress in chronic hepatitis C patients. Gastroenterol Hepatol. 2012;35:386-394. DOI:10.1016/j.gastrohep.2012.03.004

[15] Ministry of Health of Brazil. Protocolo Clínico e Diretrizes Terapêuticas para Hepatite Viral C e Coinfecções. 2011 Jul. [cited 2012 Aug 23]. Available from: http://bvsms.saude.gov.br/bvs/publicacoes/proto colos_diretrizes_hepatite_viral_c_coinfeccoes.pdf

[16] Siri WE. Body composition from fluid spaces and density. Analysis of methods. In: Brozek J, Henschel A, editors. Techniques for measuring body composition. Washington (DC): National Academy of Sciences, National Research Council; 1961. p. 223-224.

[17] Friedewald WT, Levy RI, Fredrickson DS. Estimation of the concentration of low-density lipoprotein cholesterol in plasma, without use of the preparative ultracentrifuge. Clin Chem. 1972;18:499-502.

[18] Matthews DR, Hosker JP, Rudenski AS, et al. Homeostasis model assessment: insulin resistance and $\beta$-cell function from fasting plasma glucose and insulin concentration in man. Diabetologia. 1985;23:412-419.

[19] Janaszewska A, Bartosz G. Assay of total antioxidant capacity: comparison of four methods as applied to human blood plasma. Scand J Clin Lab Invest. 2002;62:231-236.

[20] Yagi K. Simple assay for the level of total lipid peroxides in serum or plasma. Methods Mol Biol. 1998;108:101106.

[21] Nasser ALM, Dourado GKZS, Manjate DA, et al. Oxidative stress evaluation on the blood of regular consumers of orange juice. Rev Ciênc Farm Basica Apl. 2011;32:275-279.

[22] Huisman EJ, van Hoek B, van Soest $H$, et al. Preventive versus "on-demand" nutritional support during antiviral treatment for hepatitis C: a 
randomized controlled trial. J Hepatol. 2012;57:10691075. DOI:10.1016/j.jhep.2012.06.029

[23] Panchal SK, Poudyal H, Iyer A, et al. High carbohydratehigh fat diet-induced metabolic syndrome and cardiovascular remodeling in rats. J Cardiovasc Pharmacol. 2011;57:611-624. DOI:10.1097/FJC.0b013e31821b1379

[24] Hourigan LF, Macdonald GA, Purdie D, et al. Fibrosis in chronic hepatitis $\mathrm{C}$ correlates significantly with body mass index and steatosis. Hepatology. 1999;29:1215-1219.

[25] Siren R, Eriksson JG, Vanhanen H. Waist circumference a good indicator of future risk for type 2 diabetes and cardiovascular disease. BMC Public Health. 2012;12:631. DOI:10.1186/1471-2458-12-631

[26] National Academy of Sciences. DRI (Dietary Reference Intakes) for Energy, Carbohydrate, Fiber, Fat, Fatty Acids, Cholesterol, Protein, and Amino Acids (Macronutrients). 2009. [cited 2013 Feb 28]. Available from: http://www.nap.edu/

[27] Murakami Y, Nagai A, Kawakami T, et al. Vitamin E and Csupplementation prevents decrease of eicosapentaenoic acid in mononuclear cells in chronic hepatitis $\mathrm{C}$ patients during combination therapy of interferon alpha-2b and ribavirin. Nutrition. 2006;22:114-122. DOI:10.1016/j.nut.2005.05.014

[28] Vitaglione P, Fogliano V, Stingo S, et al. Development of a tomato-based food for special medical purposes as therapy adjuvant for patients with HCV infection. Eur J Clin Nutr. 2007;61:906-915. DOI:10.1038/sj.ejcn.1602571

[29] Nashaat EH. Lipid profile among chronic hepatitis C Egyptian patients and its levels pre and post treatment. Nat Sci. 2010;8:83-89.

[30] Corey KE, Kane E, Munroe C, et al. Hepatitis C virus infection and its clearance alter circulating lipids: implications for long-term follow-up. Hepatology. 2009;50:1030-1037. DOI:10.1002/hep.23219

[31] Fujino T, Nakamuta M, Yada R, et al. Expression profile of lipid metabolism-associated genes in hepatitis $\mathrm{C}$ virus-infected human liver. Hepatol Res. 2010;40:923929. DOI:10.1111/j.1872-034X.2010.00700.x

[32] Yang W, Hood BL, Chadwick SL, et al. Fatty acid synthase is up-regulated during hepatitis $\mathrm{C}$ virus infection and regulates hepatitis $\mathrm{C}$ virus entry and production. Hepatology. 2008;48:1396-1403. DOI:10.1002/ hep. 22508

[33] Andrus MR, East J. Use of statins in patients with chronic hepatitis C. South Med J. 2010;103:1018-1022. DOI:10.1097/SMJ.0b013e3181f0c6b4

[34] Butt AA, Yan P, Bonilla H, et al. Effect of addition of statins to antiviral therapy in hepatitis $C$ virus-infected persons: results from ERCHIVES. Hepatology. 2015;62:365-374.

[35] Chandra R, Dolder NM, Dolder CR, et al. Treatment of dyslipidemia with statins by primary care providers in Veterans with and without chronic Hepatitis C. Am J Health Syst Pharm. 2016;73:S30-S34. DOI:10.2146/ sp150030

[36] Mullen W, Archeveque M-A, Edwards CA, et al. Bioavailability and metabolism of orange juice flavanones in humans: impact of a full-fat yogurt. J Agric Food Chem. 2008;56:11157-11164. DOI:10.1021/jf801974v
[37] Silveira JQ, Cesar TB, Manthey JA, et al. Pharmacokinetics of flavanone glycosides after ingestion of single doses of fresh-squeezed orange juice versus commercially processed orange juice in healthy humans. J Agric Food Chem. 2014;62:12576-12584. DOI:10.1021/ jf5038163

[38] Kanaze FI, Bounartzi MI, Georgarakis M, et al. Pharmacokinetics of the citrus flavanone aglycones hesperetin and naringenin after single oral administration in human subjects. Eur J Clin Nutr. 2007;61:472-477.

[39] Kim HK, Jeong TS, Lee MK, et al. Lipid-lowering efficacy of hesperetin metabolites in high-cholesterol fed rats. Clin Chim Acta. 2003;327:129-137.

[40] Aptekmann NP, Cesar TB. Long-term orange juice consumption is associated with low LDL-cholesterol and apolipoprotein B in normal and moderately hypercholesterolemic subjects. Lipids Health Dis. 2013;12:1-10. DOI:10.1186/1476-511X-12-119

[41] Padayatty SJ, Sun H, Wang Y, et al. Vitamin C pharmacokinetics: implications for oral and intravenous use. Ann Intern Med. 2004;140:533-537.

[42] Jain SK, Pemberton PW, Smith A, et al. Oxidative stress in chronic hepatitis $\mathrm{C}$ : not just a feature of late stage disease. J Hepatol. 2002;36:805-811.

[43] Chan SW. Establishment of chronic hepatitis C virus infection. Translational evasion of oxidative defense. World J Gastroenterol. 2014;20:2785-2800. DOI:10.3748/ wjg.v20.i11.2785

[44] Paracha UZ, Fatima K, Alqahtani M, et al. Oxidative stress and hepatitis C virus. Virol J. 2013;10:251. DOI:10.1186/1743-422X-10-251

[45] Bandara P, George J, McCaughan G, et al. Antioxidant levels in peripheral blood, disease activity and fibrotic stage in chronic hepatitis C. Liver Int. 2005;25:518-526. DOI:10.1111/j.1478-3231.2005.01049.x

[46] Haidari F, Keshavarz SA, Rashidi MR, et al. Orange juice and hesperidin supplementation to hyperuricemic rats alter oxidative stress markers and xanthine oxidoreductase activity. J Clin Biochem Nutr. 2009;45:285291. DOI:10.3164/jcbn.09-15

[47] Tirkey N, Pilkhwal S, Kuhad A, et al. Hesperidin, a citrus bioflavonoid, decreases the oxidative stress produced by carbon tetrachloride in rat liver and kidney. BMC Pharmacology. 2005;5:2. DOI:10.1186/14712210-5-2

[48] Mendiratta S, Qu ZC, May JM. Erythrocyte ascorbate recycling: antioxidant effects in blood. Free Radic Biol Med. 1998;24:789-797.

[49] Padayatty SJ, Katz A, Wang Y, et al. Vitamin C as an antioxidant: evaluation of its role in disease prevention. J Am Coll Nutr. 2003;22:18-35.

[50] Nimse SB, Pal D. Free radicals, natural antioxidants, and their reaction mechanisms. RSC Adv. 2015;5:2798628006.

[51] May JM. Ascorbate function and metabolism in the human erythrocyte. Front Biosci. 1998;3:d1-d10.

[52] Ji HF, Sun Y, Shen L. Effect of vitamin E supplementation on aminotransferase levels in patients with NAFLD, NASH, and CHC: results from a meta- 
analysis. Nutrition. 2014;30:986-991. DOI:10.1016/j. nut.2014.01.016

[53] Kaur G, Tirkey N, Chopra K. Beneficial effect of hesperidin on lipopolysaccharide-induced hepatotoxicity. Toxicology. 2006;226:152-160. DOI:10.1016/j.tox.2006.06.018

[54] Renugadevi J, Prabu SM. Cadmium-induced hepatotoxicity in rats and the protective effect of naringenin. Exp Toxicol Pathol. 2010;62:171-181. DOI:10.1016/j.etp.2009.03.010

[55] Prabu SM, Shagirtha K, Renugadevi J. Naringenin in combination with vitamins $\mathrm{C}$ and $\mathrm{E}$ potentially protects oxidative stress-mediated hepatic injury in cadmium-intoxicated rats. J Nutr Sci Vitaminol. 2011;57:177-185.

[56] Black S, Kushner I, Samols D. C-reactive protein. J Biol Chem. 2004;279:48487-48490.

[57] Devaraj S, Autret BC, Jialal I. Reduced-calorie orange juice beverage with plant sterols lowers C-reactive protein concentrations and improves the lipid profile in human volunteers. Am J Clin Nutr. 2006;84:756-761. 